\title{
Experience Quality, Customer Brand Engagement, Brand Performance and Brand Loyalty to Purchase Intention
}

\author{
Clarita Tanzaretha ${ }^{1}$, Rodhiah $^{2}$ \\ ${ }^{1,2}$ Universitas Tarumanagara, Indonesia \\ clarita.115180130@stu.untar.ac.id,rodhiah@fe.untar.ac.id
}

\begin{abstract}
This study aims to empirically test experience quality, customer brand engagement and brand performance on purchase intention with brand loyalty as a mediating variable. Data collection uses a non-probability method with purposive sampling technique. A total of 238 respondents, namely customers who consumed "brand $X$ " more than once, were collected by distributing questionnaires via an online google form. The analysis technique uses SEM with the Smart PLS program. The results showed that experience quality and customer brand engagement can affect brand loyalty. In addition, experience quality, customer brand engagement and brand loyalty can affect purchase intention. However, the brand performance variable cannot affect brand loyalty. Furthermore, experience quality can mediate customer brand engagement on purchase intention. Furthermore, the brand loyalty variable can also mediate experience quality and customer brand engagement in influencing purchase intention. Finally, brand performance has no effect on purchase intention if it is mediated by brand loyalty.
\end{abstract}

\section{Keywords}

Experience quality; customer brand engagement; brand performance; brand loyalty; purchase intention.

\section{Introduction}

The food and beverage industry, especially in Indonesia, is increasing, this can be seen from the growth of the food and beverage industry, which was able to grow positively in the second quarter of 2020. In addition, the food and beverage industry can provide a large contribution to economic income in Indonesia. This must be maintained so that economic actors, especially in the food and beverage sector, continue to drive their startups. One type of food that is able to create high consumer attractiveness is a startup in the food and beverage sector "brand X" which serves food with the theme of boxed rice and the archipelago. The cause of the high level of consumption is also due to the theory of gentrification consumption, namely the increase in product consumption due to the income of high-consuming consumers (Lees et al., 2015).Promotion strategy is a concept that is close to communication science. In the promotion, there are various forms of communication learned in communication science such as advertising, publicity, communication from mouth to mouth, personal sales, and direct marketing (Amin, 2019).

This is also supported because of the reviews made by consumers, many new consumers are starting to know information about the brand so that the engagement and consumer behavior will affect the impact on purchase intention (Wu et al., 2014). Purchase intention itself can be explained through several factors because, purchase intention is important in the company to be a measure of the success of a product that has been produced (Barber et al., 2010b; Barber \& Taylor, 2013). The tendency for purchase intention to occur if consumers already have a clear perception of the product and information about the brand or product so that consumers will make transactions (Meler et al., 2016). Another impetus that can increase purchase intention is because of the attitudes 
and factors developed by the company that become a benchmark for consumer attitudes (Thio \& Rodhiah, 2021).

Maintaining consumer purchase intentions is also important for companies because with increasing purchase intentions, companies will also get profits and the possibility that will occur is that consumers will be loyal to the company (Visentin et al., 2019). In the research of Mainardes et al., (2019) which discusses experience quality, it is stated that experience quality can have a direct positive impact on purchase intention. Experience quality can be felt by consumers when they directly or indirectly have experience with a brand so that it can be attached to the memory of the consumer itself. In addition, other studies (Khan et al., 2015b; Adhikari \& Panda, 2019) which discusses brand engagement and it is found that brand engagement has a positive impact on brand loyalty both directly and indirectly.

However, research conducted by Alwi et al., (2015) regarding the effect of brand performance, industrial brand image and brand trust on customer commitment: brand loyalty as a mediating variable gives the result that brand performance has a positive influence on brand loyalty. This research was conducted in order toempirically tested experience quality, customer brand engagement and brand performance on purchase intention with brand loyalty as a mediating variable for food product customers in Jakarta. In this study, there are still differences with previous studies such as variables, research subjects, research objects and research sites.

\section{Review of Literature}

\subsection{Experience Quality}

Lemon and Verhoef (2016) experience quality shows that the perceived quality of experience is a multidimensional construct that focuses on the customer's cognitive, emotional, behavioral, sensory and social responses. The experiences felt by consumers are also involved by purchases made by customers, and can be consciously felt and associated with certain companies or brands (Klaus et al., 2013).

\subsection{Customer Brand Engagement}

Customer brand engagement occurs in the majority of online consumer behavior towards a brand (Hollebeek et al., 2019; Loureiro et al., 2017). Basically, customer brand engagement provides an explanation of the theory of the relationship between consumers and brands empirically and the support it provides for a significant and positive relationship to increase brand loyalty (Vivek et al., 2012; France et al., 2016; Dessart et al, 2016).

\subsection{Brand Performance}

Nareth, (2018) takes one attitude, namely financial ratios which have an important impact on brand performance because good and stable finances can provide adequate performance in the stage of developing strategies in the market and business sustainability. Brand performance can also be measured in non-financial terms, such as behavior, perceptions, views and also brand loyalty as outlined from each consumer's view. Thus, it is important for every company to be able to maintain and continue to evaluate strategies so that brand performance within a company can be integrated (Anisimova , 2010).

Financial statements are basically a source of information for investors as one of the basic considerations in making capital market investment decisions and also as a means of management responsibility for the resources entrusted to them (Prayoga and Afrizal 2021). 
Financial performance is a measuring instrument to know the process of implementing the company's financial resources. It sees how much management of the company succeeds, and provides benefits to the community. Sharia banking is contained in the Law of the Republic of Indonesia No.21 of 2008 article 5, in which the Financial Services Authority is assigned to supervise and supervise banks. (Ichsan, R. et al. 2021)

\subsection{Brand Loyalty}

Brand loyalty is an attachment between a brand and a customer that is considered to be able to motivate customers to a preferred brand by showing repeated purchasing behavior decisions (Pappu \& Quester, 2016). Another study also said thatThe establishment of good brand loyalty is the main goal in the company so that consumers can become loyal to the brand in their company (Selvia \& Rodhiah, 2020:363)

\subsection{Purchase Intention}

Consumer purchase intentions occur when consumers already know information about the product or service to be targeted and it is also shaped by consumer evaluations of products or attitudes towards a brand combined with external driving factors (Lin et al., 2014).

\subsection{The Relationship between Experience Quality and Purchase Intention}

Minardes et al., (2019) experience quality has the ability to influence traditional marketing such as purchase intention, perceived quality and brand equity, because experience quality has the nature of building the mindset of consumers regarding the perception of the quality of the brand and raises purchase intention from consumers and encourage consumers to buy products from the brand and the results obtained that experience quality has a positive impact on purchase intention.

\subsection{The Relationship between Experience Quality and Brand Loyalty}

The scope of experience quality is not only influenced by their own satisfaction but can also have an impact on other things such as the belief that the brand can meet their expectations so that they will start to be loyal to the brand (Raza et al., 2015). Thus, experience quality can affect brand loyalty to a brand with the experience they feel with the brand (Klaus \& Maklan, 2013).

\subsection{The Relationship between Customer Brand Engagement and Brand Loyalty}

Several previous studies explained that good customer brand engagement can have an influence on consumers and consumers will be loyal to the brand (Khan \& Rahman, 2015b; Nysveen et al., 2013). Previous research (Vivek et al., 2012) states that there is a positive influence between brand engagement and brand loyalty.

\subsection{The Relationship between Brand Performance and Brand Loyalty}

The results of previous studies show that a good brand performance shown by a company can shape a consumer's behavior so that consumers will begin to assess brand performance and consumers will become loyal to the brand (Alwi et al., 2015).

\subsection{The Relationship between Brand Loyalty and Purchase Intention}

The results of previous studies show that brand loyalty has a positive impact on purchase intention because of the interaction between consumers and the brand so that consumers tend to find it difficult to switch to other brands (Ali et al., 2020). 
2.10. The Relationship between Customer Brand Engagement and Purchase Intention The relationship that occurs between brands and consumers which results in involvement is one of the supporting factors that act directly to influence consumers' purchase intentions for products and services (France et al., 2016). Consumer involvement can also be increased and developed through transactions that occur due to purchases both online and offline so that customer brand engagement can positively influence purchase intention (Bijmolt et al., 2010).

\subsection{The Relationship between Customer Brand Engagement and Experience Quality}

The interactions between consumers and brands lead to consumer engagement tactics so as to provide a comprehensive experience of a brand (Islam et al., 2019). With continuous communication by the brand, it can provide a main point for consumers and they will assume that this is a positive side of their experience with the brand (Nysveen \& Pedersen, 2014).

\subsection{Experience Quality Mediating the Relationship between Customer Brand Engagement and Brand Loyalty \\ When a brand provides an image, service or can highlight their strengths to} consumers, most consumers naturally in their memory will form a pattern regarding the experience they feel on the brand so that the experience quality felt by consumers can mediate the influence between customer brand engagement on brand loyalty. (Islam et al., 2019; Lemon \& Verhoef, 2016). Based on the results of the above discussion, The form of the research model that will be used is as follows

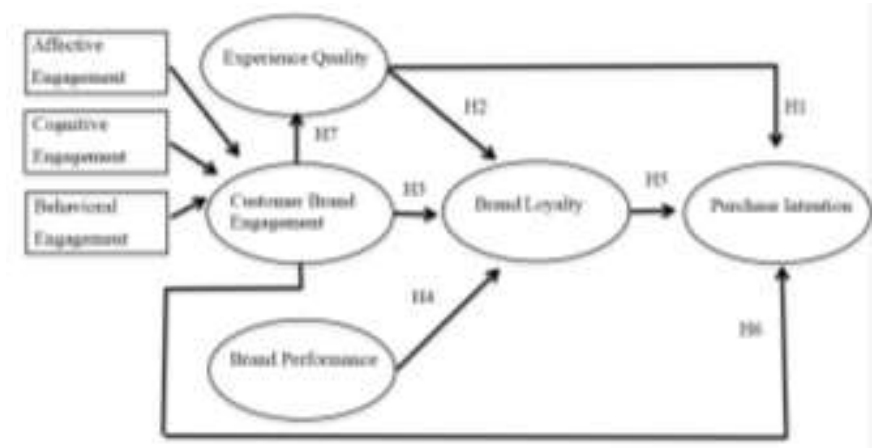

Figure 1. Research Model

\subsection{Hypothesis}

H1: There is a positive influence between experience quality on purchase intention.

H2: There is a positive influence between experience quality on brand loyalty.

H3: There is a positive influence between customer brand engagement on brand loyalty.

H4: There is a positive influence between brand performance on brand loyalty.

H5: There is a positive influence between brand loyalty on purchase intention.

H6: There is a positive influence between customer brand engagement on purchase intention.

H7: There is a positive influence between customer brand engagement on experience quality.

H8: Experience quality can mediate the positive influence of customer brand engagement on brand loyalty. 


\section{Research Method}

The population in this study are all food product customers who are domiciled in DKI Jakarta. This study uses a non-probability sampling technique with a porposive sampling technique where the researchers set special provisions with the criteria of customers who have consumed food brand " $\mathrm{X}$ " at least 2-3 times ordering and as many as 238 respondents used in this study. The technique of collecting data is using google form which is carried out by distributing questionnaires online. The data processing of this research uses PLS-SEM software which consists of two analyzes, namely outer model measurement and inner model measurement.

\section{Results and Discussion}

\subsection{Respondent Profile}

Based on the respondent's characteristic data, the majority of respondents are women $(66.5 \%)$, the last education is high school $(57.6 \%)$, then the age of the majority of respondents is $20-24$ years $(80.3 \%$ ), in addition to the occupation chosen by the majority of respondents Students (54.6\%), and finally the majority of respondents domiciled in West Jakarta $(50.7 \%)$.

\subsection{Outer Model Measurement Results Analisis a. Convergent Validity}

Table 1. Analysis Results of Average Variance Extracted (Convergent Validity)

\begin{tabular}{|c|c|}
\hline Variable & Average Variance Extracted $(\boldsymbol{A V E})$ \\
\hline Experience quality & 0.552 \\
\hline Customer brand engagement & 0.672 \\
\hline Brand performance & 0.564 \\
\hline Brand loyalty & 0.707 \\
\hline Purchase intention & 0.666 \\
\hline
\end{tabular}

Based on the results of the test data Average Variance Extracted (AVE) in Table 1 it can be concluded that each variable used in this study meets the AVE criteria where $>0.5$.

\section{b. Discriminant Validity}

Table 2. Analysis Results of Fornell-Larcker Criterion (Discriminant Validity)

\begin{tabular}{|l|c|c|c|c|c|}
\hline Indicator & $\begin{array}{l}\text { Brand } \\
\text { Loyalty }\end{array}$ & $\begin{array}{l}\text { Brand } \\
\text { Performance }\end{array}$ & $\begin{array}{l}\text { Customer } \\
\text { Brand } \\
\text { Engagement }\end{array}$ & $\begin{array}{l}\text { Experience } \\
\text { Quality }\end{array}$ & $\begin{array}{l}\text { Purchase } \\
\text { Intention }\end{array}$ \\
\hline Brand Loyalty & 0.841 & & & & \\
\hline $\begin{array}{l}\text { Brand } \\
\text { Performance }\end{array}$ & 0.510 & 0.751 & & & \\
\hline $\begin{array}{l}\text { Customer Brand } \\
\text { Engagement }\end{array}$ & 0.762 & 0.514 & 0.820 & & \\
\hline $\begin{array}{l}\text { Experience } \\
\text { Quality }\end{array}$ & 0.662 & 0.644 & 0.579 & 0.743 & 0.816 \\
\hline $\begin{array}{l}\text { Purchase } \\
\text { Intention }\end{array}$ & 0.840 & 0.472 & 0.767 & 0.693 & \\
\hline
\end{tabular}


Based on the results of the Fornell-Larcker criterion analysis in Table 2, the AVE square root value of each construct is greater than the other latent variables.

\section{c. Reliability}

Table 3. Analysis Results of Composite Reliability and Coeficient Cronbach's Alpha .

\begin{tabular}{|c|c|c|}
\hline Variable & Composite Reliability & Coefficient Cronbach's Alpha \\
\hline Experience quality & 0.786 & 0.613 \\
\hline $\begin{array}{c}\text { Customer brand } \\
\text { engagement }\end{array}$ & 0.860 & 0.756 \\
\hline Brand performance & 0.792 & 0.607 \\
\hline Brand loyalty & 0.906 & 0.862 \\
\hline Purchase intention & 0.888 & 0.831 \\
\hline
\end{tabular}

Based on the results in Table 3 it can be concluded that all variables in this study meet the criteria for composite reliability where 0.7 and the minimum requirement of Cronbach's alpha coefficient where $>0.6$ have also been met so that the variables in this study can be used.

\subsection{Result of Inner Model Measurement a. R-Square (R2) Analysis}

Table 4. R-Square (R2) analysis results

\begin{tabular}{|c|c|c|}
\hline Variable & R-Square & R-Square Adjusted \\
\hline Brand loyalty & 0.654 & 0.649 \\
\hline
\end{tabular}

Based on the table above, the R-valueSquare(R2) can be manifested if 0.5 to 0.74 which means it has a moderate effect. So that $65.4 \%$ can be explained by brand loyalty and the remaining $34.6 \%$ can be explained by other variables that are not used in this study.

\section{b. Test of predictive relevance $(\mathbf{Q} 2)$}

Table 5. Predictive relevance test results (Q2)

\begin{tabular}{|c|c|}
\hline Variable & Predictive Relevance (Q2) \\
\hline Brand loyalty & 0.450 \\
\hline Experience quality & 0.172 \\
\hline Purchase intention & 0.501 \\
\hline
\end{tabular}

Based on the table above the value ofpredictive relevance $(\mathrm{Q} 2)$ can predict the model well if the value is > 0 (Hair et al., 2017). It can be seen that the results of the predictive relevance test $(\mathrm{Q} 2)$ or construct cross-validated redundancy on the brand loyalty variable are 0.450 while the experience quality variable is 0.172 and the purchase intention variable is 0.501 , which means that each variable can predict the research model well. 
Table 6. Effect size test results (f2)

\begin{tabular}{|c|c|c|c|c|c|}
\hline & $\begin{array}{c}\text { Experience } \\
\text { Quality }\end{array}$ & $\begin{array}{c}\text { Customer } \\
\text { Brand } \\
\text { Engagement }\end{array}$ & $\begin{array}{c}\text { Brand } \\
\text { Performance }\end{array}$ & $\begin{array}{c}\text { Brand } \\
\text { Loyalty }\end{array}$ & $\begin{array}{c}\text { Purchase } \\
\text { Intention }\end{array}$ \\
\hline $\begin{array}{c}\text { Experience } \\
\text { Quality }\end{array}$ & & & & $\mathbf{0 . 1 5 7}$ & $\mathbf{0 . 1 0 4}$ \\
\hline $\begin{array}{c}\text { Customer } \\
\text { Brand } \\
\text { Engagement }\end{array}$ & $\mathbf{0 . 5 0 4}$ & & & $\mathbf{0 . 5 8 9}$ & $\mathbf{0 . 1 2 5}$ \\
\hline $\begin{array}{c}\text { Brand } \\
\text { Performance }\end{array}$ & & & & $\mathbf{0 . 0 0 0}$ & \\
\hline $\begin{array}{c}\text { Brand } \\
\text { Loyalty }\end{array}$ & & & & & $\mathbf{0 . 3 7 1}$ \\
\hline $\begin{array}{c}\text { Purchase } \\
\text { Intention }\end{array}$ & & & & & \\
\hline
\end{tabular}

From the results obtained in the testeffect size(f2), the variable customer brand engagement has the greatest influence on brand loyalty as a mediating variable. In addition, the minimum requirements for testing the effect size (f2) are $<0.02 ;<0.15$ and $<0.35$ however, if there is a test result $<0.002$ then the variable has no influence or effect on the research (Hair et al., 2017).

\section{c. Path-coefficient analysis}

Table 7. Path-coefficient analysis results

\begin{tabular}{|l|c|c|c|c|}
\hline Variable & $\begin{array}{c}\text { Path- } \\
\text { coefficient }\end{array}$ & t-statistics & P-values & Description \\
\hline $\begin{array}{l}\text { Experience Quality } \rightarrow \\
\text { Purchase Intention }\end{array}$ & 0.209 & 4,117 & 0.000 & Positive \\
\hline $\begin{array}{l}\text { Experience Quality Bnd } \\
\text { Loyalty }\end{array}$ & 0.330 & 5,469 & 0.000 & Positive \\
\hline $\begin{array}{l}\text { Customer brand engagement } \rightarrow \\
\text { Brand Loyalty }\end{array}$ & 0.568 & 11,527 & 0.000 & Positive \\
\hline $\begin{array}{l}\text { Brand Performance } \rightarrow \\
\text { Brand Loyalty }\end{array}$ & 0.005 & 0.088 & 0.465 & Positive \\
\hline $\begin{array}{l}\text { Brand loyalty } \rightarrow \\
\text { Purchase intention }\end{array}$ & 0.499 & 7,014 & 0.000 & Positive \\
\hline $\begin{array}{l}\text { Customer brand engagement } \rightarrow \\
\text { Purchase Intention }\end{array}$ & 0.266 & 4.034 & 0.000 & Positive \\
\hline $\begin{array}{l}\text { Customer brand engagement } \rightarrow \\
\text { Experience Quality }\end{array}$ & 0.579 & 12,025 & 0.000 & Positive \\
\hline $\begin{array}{l}\text { Customer brand engagement } \rightarrow \\
\text { Experience Quality } \rightarrow \\
\text { Brand Loyalty }\end{array}$ & 0.191 & 4,852 & 0.000 & Positive \\
\hline
\end{tabular}

Based on the results of the path-coefficient analysis with the PLS Algorithm technique, all variables used have a positive direction. The results of the t-statistics used for testing the hypothesis that each variable used in this study was accepted because it was in accordance with the $\mathrm{t}$-statistic criteria, namely $\mathrm{t}<1.96$ (Hair et al., 2017). In addition, the test p-value must be less than 0.05 (P-value 0.05). 


\subsection{Discussion}

In the hypothesis testing that has been done, it is found that $\mathrm{H} 1$ is not rejected, which means it can have a positive and significant impact on purchase intention. This is in line with the research resultsMinardes et al., (2019) that experience quality can affect purchase intention in a way to keep building a pleasant experience in the eyes of consumers. $\mathrm{H} 2$ is not rejected, which means it can also positively affect brand loyalty and this is in line with researchRaza et al., (2015) that experience quality can affect brand loyalty positively and significantly. $\mathrm{H} 3$ is not rejected which meanscan positively affect brand loyalty and this is in line with research by Vivek et al., (2012) that the stronger the engagement between consumers and the brand, the effect of consumer loyalty with the brand. $\mathrm{H} 4$ is rejected, which means that it cannot have a positive and significant effect between brand performance on brand loyalty, however, this is not in line with the results of research by Alwi et al., (2015) which causes that the level of performance of a brand cannot affect the increase in brand loyalty. H5 is not rejected, which means it can have a positive and significant impact on purchase intention and the results of this study are in line withAli et al., (2020) that consumer behavior towards these brands can lead to repeated purchases and consumers tend to find it difficult to switch to other brands. H6not rejected, which means it can positively and significantly affect purchase intention and is in line with the results of France et al., (2016) that when there is interaction with consumers, it can encourage consumer behavior to increase the power of purchase intention on a brand. $\mathrm{H} 7$ is not rejected, which means it can have a positive and significant impact on experience quality and this is in line with the results of Islam et al., (2019) where the experience felt by consumers is not only through the taste image given but can be from delivery, packaging and other things. which causes consumers to feel satisfaction when making transactions on a brand. $\mathrm{H} 8$ is not rejected, which means that experience quality can mediate positively and significantly between customer brand engagement and brand loyalty.

\section{Conclusion}

Based on the results of data processing and the explanation that has been given, the conclusion from this study, namely, experience quality and customer brand engagement can positively influence purchase intention and brand loyalty as mediating variables. In addition, brand performance can not positively affect brand loyalty. Meanwhile, experience quality can positively mediate the influence of customer brand engagement on brand loyalty.

\section{References}

Adhikari, K., \& Panda, R. K. (2019). The Role of consumer- brand engagement towards driving brand loyalty: Mediating effect of relationship quality. Journal of Modelling in Management, 14(4), 987-1005.

Ali, A., Xiaoling, G., Sherwani, M., \& Ali, A. (2017). Factors affecting Halal meat purchase intention: evidence from international Muslim students in China.

British Food Journal, 119(3), 527-541.

Amin, M. et al. (2019). Marketing Communication Strategy To Improve Tourism Potential. Budapest International Research and Critics Institute-Journal (BIRCIJournal). P. 160-166.

Alwi, S. F. S., Nguyen, B., Melewar. T.C., Loh, Y. H., \& Liu, M. (2015). Explicating industrial brand equity Integrating brand trust, brand performance and 
industrial brand image. Journal of Industrial Management \& Data Systems,116(5), 858-882.

Anisimova, T. (2010). Corporate brand: the company-customer misalignment and its performance implications. Journal of Brand Management, 17(7), 488-503.

Barber, N. A., Taylor, D. C., \& Strick, S. (2010b). Wine consumers' environmental knowledge and attitudes: influence on willingness to purchase. International Journal of Wine Research, 1, 59-72.

Barber, N. A., \& Taylor, D. C. (2013). Experimental approach to assessing actual wine purchase Behavior. International Journal of Wine Business Research, 25(3), 203-226.

Bijmolt, T. H., Leeflang, P. S. H., Block, F., Eisenbeiss, M., Hardie, B. G. S., Lemmens, A., \& Saffert, P. (2010). Analytics for customer engagement. Journal of Service Research, 13(3), 341-356.

Dessart, L., Veloutsou, C., \& Morgan-Thomas, A. (2016). Capturing consumer engagement: duality, dimensionality and measurement. Journal of Marketing Management, 32(5/6), 399-426.

France, C., Merrilees, B., \& Miller, D. (2016). An integrated model of customerbrand engagement: drivers and consequences. Journal of Brand Management, 23(2), 119-136.

Hair, J. F., G. T. M. Hult, C. M. Ringle, \& M. Sarstedt. (2017). A Primer on Partial Least Squares Structural Equation Modeling (PLS-SEM), 2nd edn. Thousand Oaks, CA: Sage.

Hollebeek, L., Srivastava, R.K., \& Chen, T. (2019). S-D logic-informed customer engagement: integrative framework, revised fundamental propositions, and application to CRM. Journal of the Academy of Marketing Science, 47(1),161185.

Ichsan, R. et al. (2021). Determinant of Sharia Bank's Financial Performance during the Covid-19 Pandemic. Budapest International Research and Critics Institute-Journal (BIRCI-Journal). P. 298-309.

Islam, J. U., Rahman, Z., \& Hollebeek, L. D. (2018). Consumer engagement in online brand communities: a solicitation of congruity theory. Internet Research, 28(1), 23-45.

Khan, I., \& Rahman, Z. (2015b). Brand experience anatomy in retailing: an interpretive structural modeling approach. Journal of Retailing and Consumer Services, 24(5), 60-69.

Klaus, P., Gorgoglione, M., Buonamassa, D., Panniello, U., \& Nguyen, B. (2013). Are you providing the 'right' customer experience? The case of Banca

Popolare di Bari. International Journal of Bank Marketing, 31(7), 506-528.

Lees, L., Shin, H. B., \& Lopez-Morales, E. (2015). Conclusion: global gentrifications. In L. Lees, H. B. Shin, \& E. Lopez-Morales (Eds.), Global Gentrifications. Uneven development and displacement, 441-452.

Lemon, K., \& Verhoef, C. P. (2016). Understanding customer experience throughout the customer journey. Journal of Marketing, 80(6), 69-96.

Mainardes, E. W., Gomes, V. C. A., Marchiori, D., Correa, L. E., \& Guss, V. (2019). Consequences of customer experience quality on franchises and nonfranchises models. International Journal of Retail \& Distribution Management, 47(3), 311-330

Meler, M., Horvat, D., \& Kristic, J. (2016). Wine consumer traits. Journal of Marketing, 70. 
Narteh, B. (2018). Brand equity and financial performance: the moderating role of brand likeability. Marketing Intelligence and Planning, 36(3), 381-395.

Nugraha, D. (2020). Bisnis Food and Baverage Industri 4.0, Tantangan dan Cara Menghadapinya.https://www.paper.id/blog/bisnis/food-and-beverage-fnb/. Diakses 18 september 2021.

Pappu, R., \& Quester, P. G. (2016). How does brand innovativeness affect brand loyalty?. European Journal of Marketing, 50(1-2), 2-28.

Raza, M., Frooghi, R., Binti Rani, S. H., \& Qureshi, M. A. (2018). Impact of brand equity drivers on purchase intention: a moderating effect of entrepreneurial marketing. South Asian Journal of Management Sciences, 12(1), 69-92.

Selvia \& Rodhiah. (2020). Pengaruh Personality Traits Terhadap Brand Loyalty Melalui Congruity dan Customer Satisfaction Sebagai Variabel Mediasi pada Brand Fore Coffee. Jurnal Manajerial dan Kewirausahaan, 2(2), 361- 370.

Thio, Y. J., \& Rodhiah. (2021). PENGARUH SERVICE ENCOUNTER QUALITY, BRAND ATTITUDE, IMAGE, TRUST TERHADAP CUSTOMER LOYALTY DI GARUDA INDONESIA. Jurnal Manajerial dan Kewirausahaan, 3(4), 1019-1028.

Wu, H.-C., \& Li, T. (2014). A study of experiential quality, perceived value, heritage image, experiential satisfaction, and behavioral intentions for heritage tourists. Journal of Hospitality \& Tourism Research, 41(8), doi: https://doi.org/10.1177/1096348014525638.

Visentin, M., Pizzi, G., \& Pichierri, M. (2019). Fake news, real problems for brands: the impact of content truthfulness and source credibility on consumers behavioral intentions toward the advertised brands. Journal of InteractiveMarketing, 45, 99-112.

Vivek, S. D., Beatty, S. E., \& Morgan, R. M. (2012). Customer engagement: exploring customer relationships beyond purchase. Journal of Marketing Theory and Practice, 20(2), 122-146. 